\title{
Simulation of oscillating water movement in the laboratory for cultivation of shallow water sedentary organisms
}

\author{
A. SVOBODA \\ 1. Zoologisches Institut der Universität Wien; Wien, Austria
}

KURZFASSUNG: Simulation oszillierender Wasserbewegung im Labor zur Kultivierung sedentärer Organismen des Seichtwassers. An Aglaopbenia (Hydroidea) wurden Freiland- und Aquarienexperimente zur Frage der Orientierung zur Strömungsrichtung durchgeführt. Es wurde durch Freilanduntersuchungen festgestellt, daß Aglaophenia pluma (L.) durch ihren besonderen Standort an langen, biegsamen Algen stets dorsal und senkrecht zur Strömung orientiert vorkommt. Eine Variation dieser Art, Aglaophenia pluma var. teissieri, wächst auf festem Substrat und läßt eine Orientierung nur senkrecht zur Strömung, nicht aber eine Dorsalorientierung erkennen, da sie im seichten Litoral, in der Zone des durch Wellen bewegten Wassers, vorkommt. Bei Verdrehung der Kolonien im Freiland konnte durch fotografische Bestandsaufnahme bewiesen werden, daß eine Neuorientierung mit dem vorherigen Abwerfen der Fächer und mit einem Neuaufwuchs verbunden ist. In Laborexperimenten wurde bei strömender Wasserbewegung nur eine geringe Aufwuchsrate nach dem Abwerfen der alten Fächer erhalten, doch zeigt die auf festem Substrat wachsende Aglaophenia pluma var. teissieri unter diesen Bedingungen eine eindeutige Orientierung dorsal und senkrecht zur Strömungsrichtung. Erst die dem Biotop eigene Wasserbewegung, die Wasserschwingung, erbrachte eine wesentliche Erhöhung der Aufwuchsrate an Fächern. Schütteleinrichtungen und langgestreckte, durch Schaukeln bewegte Aquarien wurden für die erforderlichen Experimente als unzulänglich erkannt. Statt dessen wurde eine besondere Pumpe verwendet. Ein über einen Exzenter und Seilrollen hebbarer Kolben verdrängt über ein Verbindungsrohr das Meerwasser aus dem Zylinder, in den er eingesenkt wird, in ein Ausgleichsgefäß. Im Verbindungsrohr entsteht eine Maximalgeschwindigkeit des Wassers von $1,6 \mathrm{~m} / \mathrm{sec}$; die Periode beträgt $7 \mathrm{sec}$. Die Montage der Substratstïcke erfolgt in Polystyrolschaumzylindern durch Einsenken und Drahtfixierung. Diese Zylinder werden im Verbindungsrohr in ein Führungsprofil eingeschoben und können mittels Drehstangen von außen her gedreht werden. Eine von 6 Montagestellen rotiert permanent mit 1 Umdrehung/min. Die bei symmetrischer Wasserschwingung zu erwartende Gleichverteilung der Dorsalorientierung ist nur in der Mitte des Substratstiickes verwirklicht, an den Rändern tritt durch Wirbelbildung eine Schwächung einer Strömungskomponente auf, die eine Dorsalorientierung zum Substratrand bewirkt. Dauerrotierende Substratstïcke zeigen unerwarteterweise keine Zufallsverteilung an Fächern, sondern eine Fächerstellung parallel zu den vor dem Versuch im Freiland aufgewachsenen Fächern. Eine Ozonisierung des Meerwassers erwies sich zur Erzielung langfristigen Wachstums als vorteilhaft.

\section{INTRODUCTION}

Water movement transports oxygen, food and sediments to sessile organisms and facilitates the removal of metabolic end products, $\mathrm{CO}_{2}$ as well as sediments. According 
to RIEDL's (1964) classification of the types of water movement in exposed localities, oscillations predominate over currents down to a waterdepth of $20 \mathrm{~m}$.

Fan-shaped sessile organisms orientate perpendicular to the direction of water currents. WAINWRIGHT (1968), using models of sea-fans (Gorgonia flabellum), was able to support the statement of Theodor \& Denizot (1965) that such orientation of the fans represents the most stable position from a mechanical point of view. Orientation parallel to the direction of the current causes strong twisting movements even in cases of slight current deviations. There is no doubt that the perpendicular fan position is also most convenient for food collection. However, in algae or sedentary organisms living solely on their symbionts, the latter argument is without importance for positioning relative to water movement.

The hydroid Aglaopbenia pluma, growing on the stems of Cystoseira sp., orientates in a striking way its dorsal surface to the base of the algae; on stable substrate the dorsal-ventral orientation seems to be accidental.

\section{METHODS AND RESULTS}

Experiments were carried out both in the field and in the laboratory on the re-orientation of fans of Aglaophenia pluma. As test organism, I have chosen a variation of $A$. pluma which carries no symbionts, namely $A$. pluma var. teissieri (PICCARD, unpublished). This variation grows on rocky substrates and can be reared in darkness, unlike the symbiont bearing form, which grows only on algae in the northern Adriatic Sea.

In field experiments, pieces of rock bearing Aglaophenia pluma var. teissieri were chiselled off, turned 90 degrees, and refastened with wire. The subsequent reorientation of the fans was controlled with a camera especially designed for this test. One month after initiation of the field experiment only a few fans were observed; they were smaller than the original ones and had grown in a direction which was different by an angle of 90 degrees. It seems that fully grown fans of $A$. pluma var. teissieri cannot turn (unlike those of Gorgonia flabellum) but are cast off the stolons and that the new fans orientate again perpendicular to the prevailing water current. There was an increased number of fans coiled in a spiral form. Obviously these had just begun to develop at the moment at which the piece of rock was turned and were able to continue to grow in the new direction. Our field experiments were intended as a control for laboratory studies; as they depend too much on noncontrollable conditions, and - since there were no facilities for microscopic studies available - they do not allow detailed analyses.

The laboratory experiments were carried out in Vienna (Austria), because the institute in Rovinj (Jugoslavia) could not provide equipment suitable for maintaining the hydroids. Pieces of rock (5-10 cm in diameter), bearing thick growths of A. pluma var. teissieri, were transported, during the cold part of the year (with the aid of filters and an air supply) to Vienna. In our laboratory they were placed into running synthetic seawater of habitat temperature and salinity (Fig. 1). The water was cooled (glass tube connection to refrigerator) and filtered (hydraffin charcoal). 
Ozonisation can be recommended if the ozone is destroyed before it reaches the aquarium.

The velocity of the water current was $30-50 \mathrm{~cm} / \mathrm{sec}$ in the vicinity of the polyps. Under the cultivation conditions described, the fans are cast off after 1-2 weeks but grow again, less in number, from the remaining stumps. All of them turn their dorsal surface against the direction of the water current. This explains the

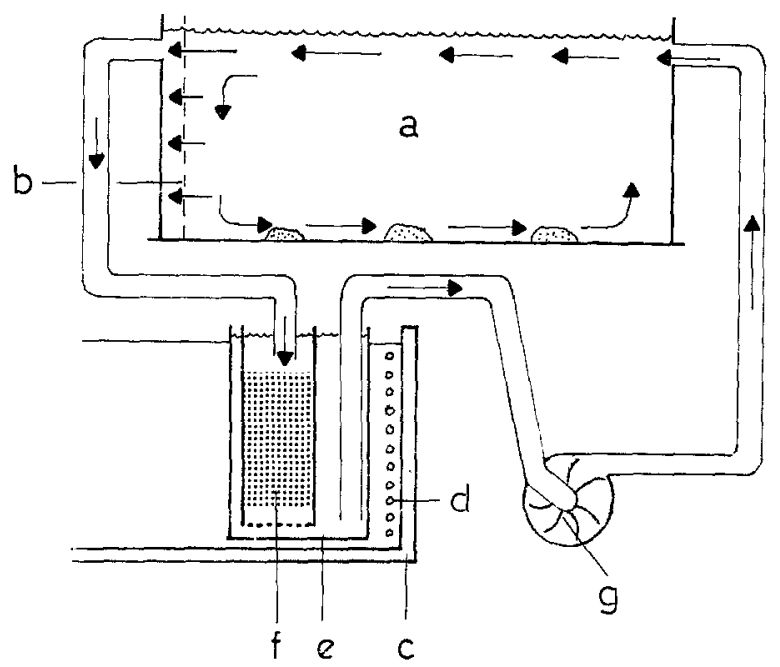

Fig. 1: Aquarium with seawater circuit used for maintenance of Aglaophenia pluma. a aquarium, $b 50 \mu \mathrm{m}$ nylon net, $c$ isolated PVC container for coolant ( $\mathrm{MgCl}_{2}$-CaCl2-solution), $d$ cooling coils, $e$ accumulator tank glass, $f$ hydraffin charcoal, $g$ centrifugal pump

arrangement of the fans on the Cystoseira stems: the algae float in the direction of the water current and their epigrowth always receives the current from the same side. Further turning experiments were not conducted because it was not possible to obtain significant regrowth rates (about $1 \%$ of the original number of fans per week) not even in natural sea water, after special filtration or in varying current speeds, so I tried a change in the water movement direction. In the natural habitat of Aglaophenia pluma var. teissieri - shallow littoral areas of $0.5-6 \mathrm{~m}$ depth - pendulation is the dominating component of water movement. There are several possibilities to simulate water pendulation under laboratory conditions.

In chemistry and biology, shaking devices have been in use for decades (Fig. 2a). They have proven useful for plankton cultures and for cultivation of athecate hydroids (PAFFENHöFER 1968). However, for my purposes, the shaking rhythm is too fast and the cooling and filtration of the water too difficult. In addition, microscopic observation is practically impossible during shaking.

For feeding experiments on chthamalids, KLEPAL (1969) used successfully an apparatus, designed by RIEDL, which we have named "Schaukel" (Fig. 2b). This apparatus consists of a long aquarium, which is forced into swinging motions by an excenter. However, this device was also unsuitable for my studies: the substrate 
pieces attached in the middle region of the aquarium emerged after each swinging and the swinging periods were too short. Cooling, filtration and observation turned out to be just as difficult as with the shaking method.

Finally, I tried to employ a pump connected to a water current canal (Fig. 2c). The piston of the vertically arranged pump consists of a cylinder, filled with water

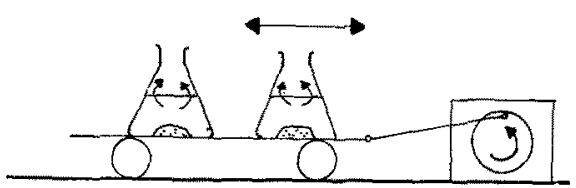

a

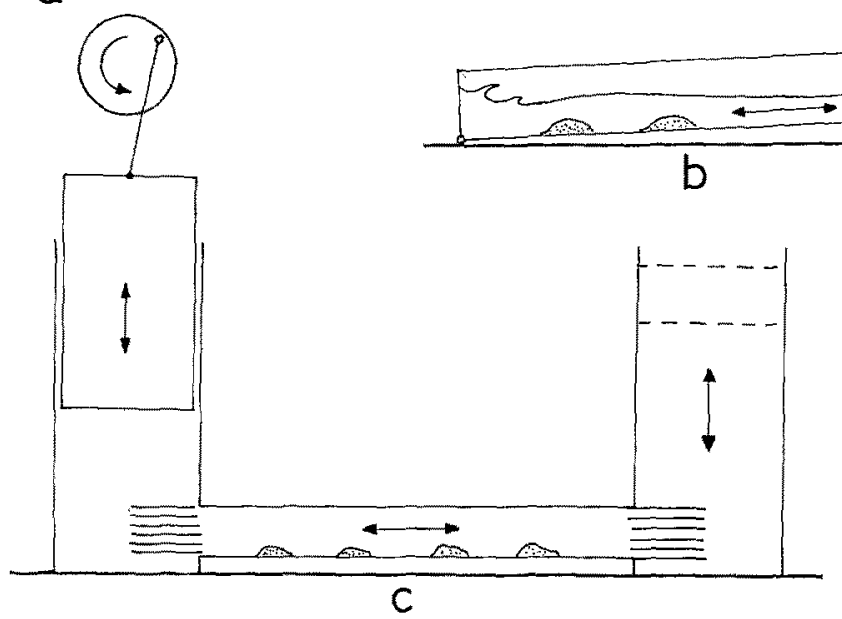

Fig. 2: Techniques of producing water movement. $a$ shaking device for culture flasks, $b$ swinging aquarium, $c$ cylinder pump contected to experimental tube and compensatory cylinder

and gliding up and down in another cylinder, a few millimeters wider. As the smaller cylinder moves down, water from the wider cylinder is forced via a tube into a compensatory cylinder (Fig. 2c, right). As the cylinder moves up, the water flows (by gravity and by adhesion) back.

Cylinder and piston are made of PVC. The cylinder is $40 \mathrm{~cm}$ wide and $80 \mathrm{~cm}$ high. The piston is $60 \mathrm{~cm}$ long and contains 501 water. It displaces 401 water during maximum stroke length $(31 \mathrm{~cm})$. The connecting tube is made of plexiglass. It is $70 \mathrm{~cm}$ long and $200 \mathrm{~cm}^{2}$ wide and contains the test animals (Fig. 2c, middle). Half of the tube's cross section $-100 \mathrm{~cm}^{2}-$ is used for fixing the substrate pieces to the tube wall. A cylinder pumping cycle of $7 \mathrm{sec}$ produces a maximum water movement velocity of $1.6 \mathrm{~m} / \mathrm{sec}$. This velocity can be reduced stepwise to $100 \mathrm{~cm} / \mathrm{sec}$ or $70 \mathrm{~cm} / \mathrm{sec}$ by shortening the length of the stroke.

The apparatus contains 1201 of sea water filtered by a hydraffin charcoal (EHEm-filtering device) and is ozonised after Hückstedt (1963). The cooling system used is the same as that used for the previous types of experiment. Without this 
cooling system the temperature will rise $3^{\circ} \mathrm{C}$ above room temperature through the self-heating caused by friction and turbulence in the apparatus. The pump is operated by a 0.5 hp motor with $9 \mathrm{rpm}$ (Fig. 3).

Observation of the animals cultivated in the connecting tube is possible from three sides. In order to avoid turbulence at the ends of the tube it is divided horizontally and vertically by plexiglass plates. On the right side near the compensating

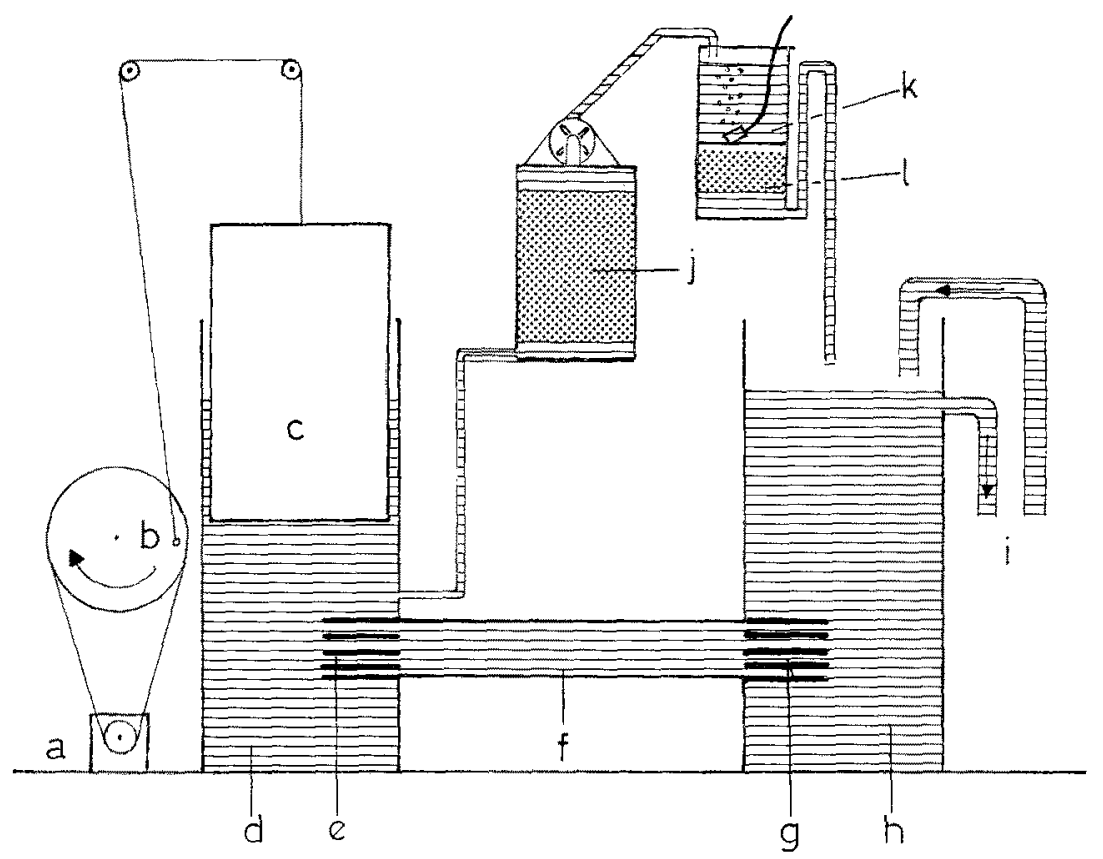

Fig. 3: Design of apparatus. $a 0.5$ hp electromotor, $b$ excenter, $c$ piston, $d$ cylinder, $e, g$ tube divided vertically and horizontally by plexiplates, $f$ plexi tube, $b$ compensating container, $i$ tubes, connected to refrigerator, $j$ EHEIM-filter, loaded with hydraffin charcoal, $k$ ozonization contact tube, $l$ hydraffin charcoal for destroying the surplus of ozone

container the plates can be removed. Two sliding ledges allow the insertion of two blocks of styropor $10 \times 10 \times 35 \mathrm{~cm}$. The back of the connecting tube is provided with 6 crossbars for turning the pieces of substratum. The crossbars are sealed off by O-rings.

The pieces of substratum are mounted on cylinders of styropor $8 \mathrm{~cm}$ in diameter and $10 \mathrm{~cm}$ long (Fig. 4). With a soldering iron adapted with a loop of silver wire a hole is melted in the styropor cylinder and the substratum fitted and secured with stainless steel wire. The cylinder has a slit at its back. Three styropor cylinders fit into the three PVC coated cylindrical holes in each block of styropor. Through the compensating cylinder two of these blocks are inserted in the plexi-tube and secured by fixing the device for avoiding the whirls. The crossbars which are withdrawn while inserting the blocks are now pushed into the slits of the styropor cylinders and 
allow turning of the substrate pieces. One of the crossbars is connected to a motor which keeps it rotating continuously at one rotation per minute.

Without ozonisation the results depended on the degree of water change; 2-3 days after water change $20-30 \%$ of the fans started to grow, but were cast off after
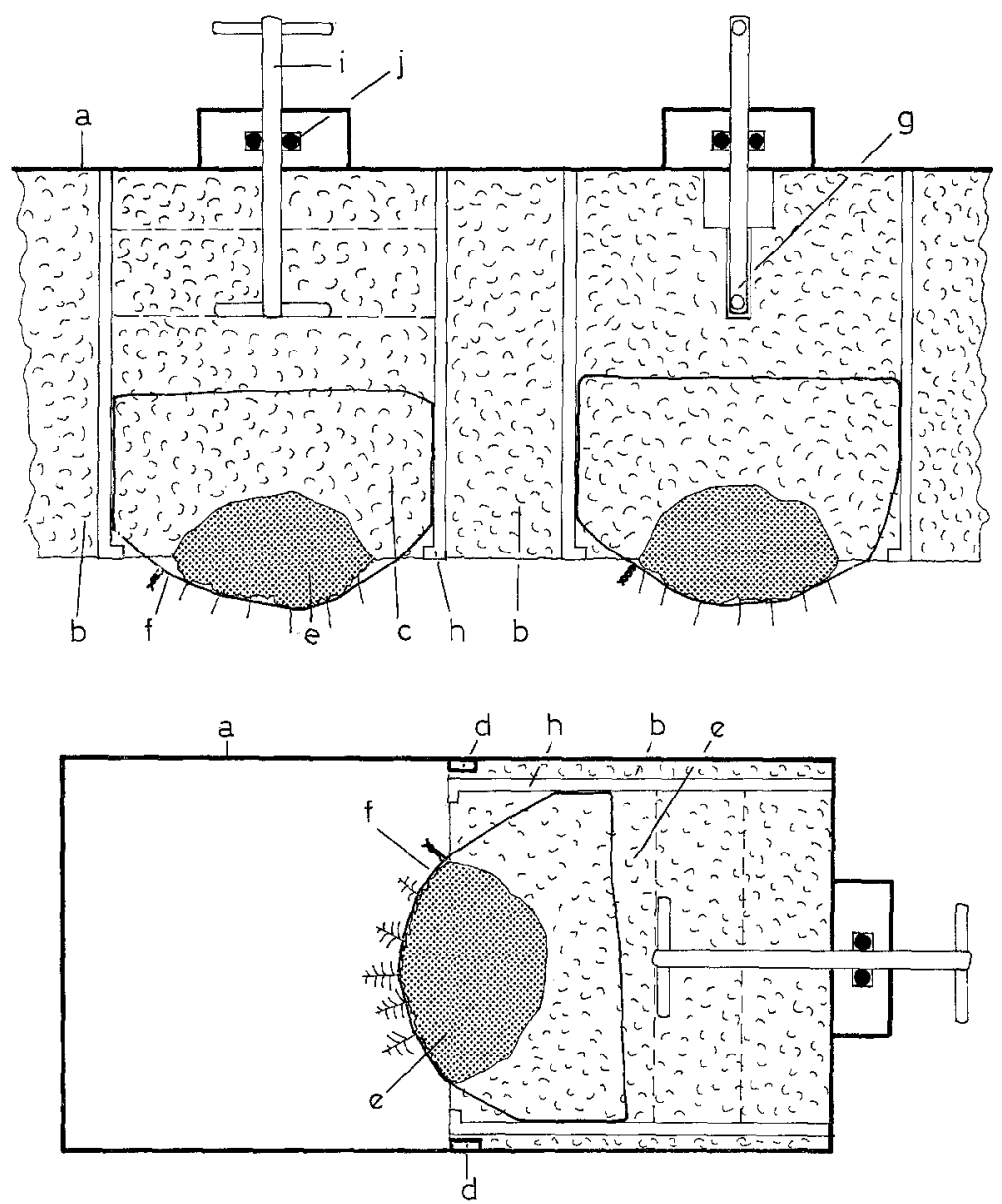

Fig. 4: Longitudinal and cross section of mounting and turning device for substrate pieces. $a$ wall of the plexitube, $b$ styropor block, $c$ styropor cylinder, $d$ sliding ledges for the styropor block, $e$ substratum pieces, $f$ stainless steel wire, $g$ slit in the cylinder with inserted crossbar, $b$ PVC-coating, $i$ stainless steel crossbar, $j$ O-ring

two weeks. After ozonizating a continuous growth could be obtained over a period of several months. If the ozonizator fails to work, the fans disappear within a few days. The direction of the fans is strictly perpendicular to the direction of the current. On the upper and lower margin of the stone there appears up to 15 degrees deviation caused by whirls.

The formation of whirls may be shown by photographing the small air bubbles 
(Fig. 5). If air bubbles are injected by a capillary tube, the whirls produce antagonistic currents in a region of the substratum, where it seams to have no currents at all (Fig. 6a). As a result all the fans orientate their dorsal region toward the margin of the stone, on the left and right margin of the substratum. This strict ventral-dorsal orientation is lost in the middle region of the stone (Fig. 6b).

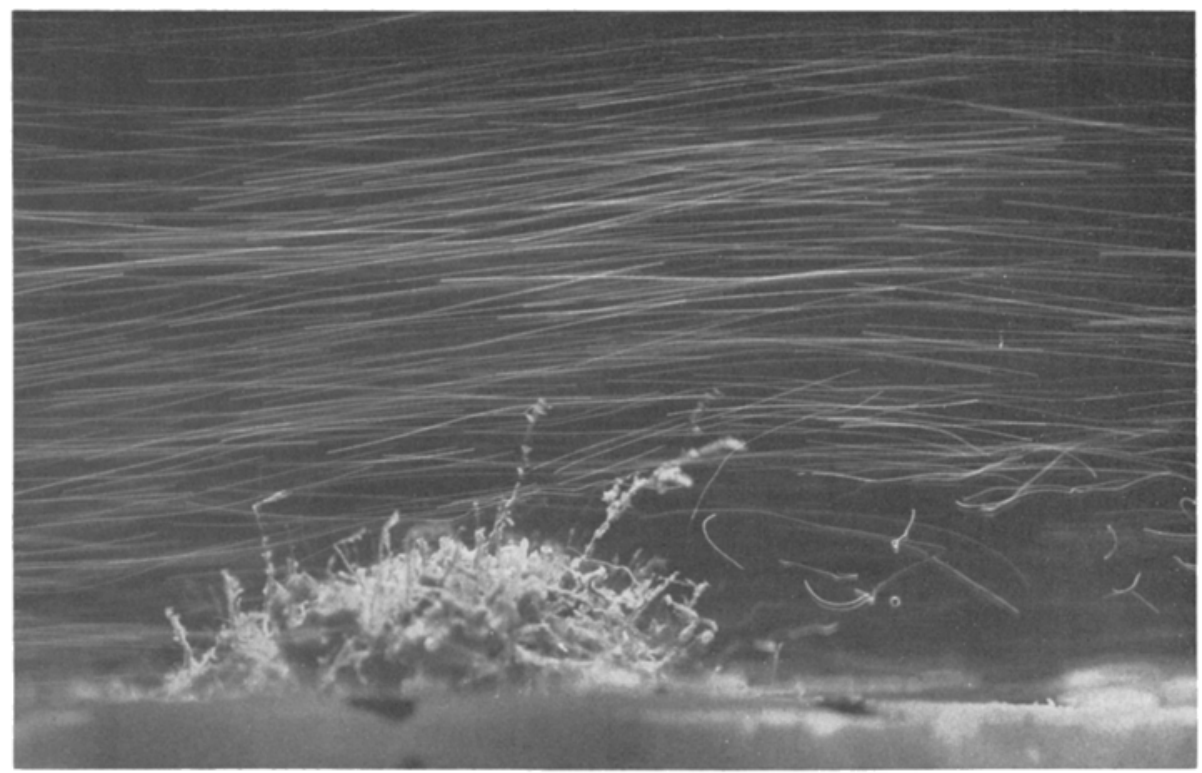

Fig. 5: Whirls, caused by the substrate block, made visible by photographing air bubbles. Water flow direction: from left to right

The growth rate per day was approximately 1 polyp on the cladus. Some fans developed nearly 30 polyps in 2 weeks. In the following week or the following 2 weeks the polyps mostly disappeared presumably due to insufficient amounts of food. In a newly developed fan, the first bud of a polyp can be twisted 30 degrees only. The result is a fan growing up helically twisted. In the field, helical growth may be assumed to have been caused by currents of alternating directions, effective during development.

Experiments with permanently rotated colonies have shown surprising results. I expected random arrangement of the fans; however, the fans grew up nearly parallel to each other. A comparison with photographs taken before the cast off of the fans reveals that the new fans grow parallel to the old ones. Hence fan direction may also be affected by the orientation of the stolons, or via internal structures of the stump which remains after the loss of the previous fan. There remain many problems of epigrowth and orientation of the fans of Aglaophenia pluma var. teissieri. We intend to solve them in further experiments.

In the near future we plan the following experiments: Substrate pieces will be turned slowly $90^{\circ}$ and back in order to find out whether the resulting fan position 
represents a mean value of the different current directions experienced. To avoid whirls, plain pieces of substratum will be used to investigate the effect of assymmetric water oscillation on the dorsal-ventral orientation. As a preliminary for these experiments I mounted glass-plates in the field a year ago. Now they are overgrown by crowded fans of Aglaophenia pluma var. teissieri which will be investigated this year.

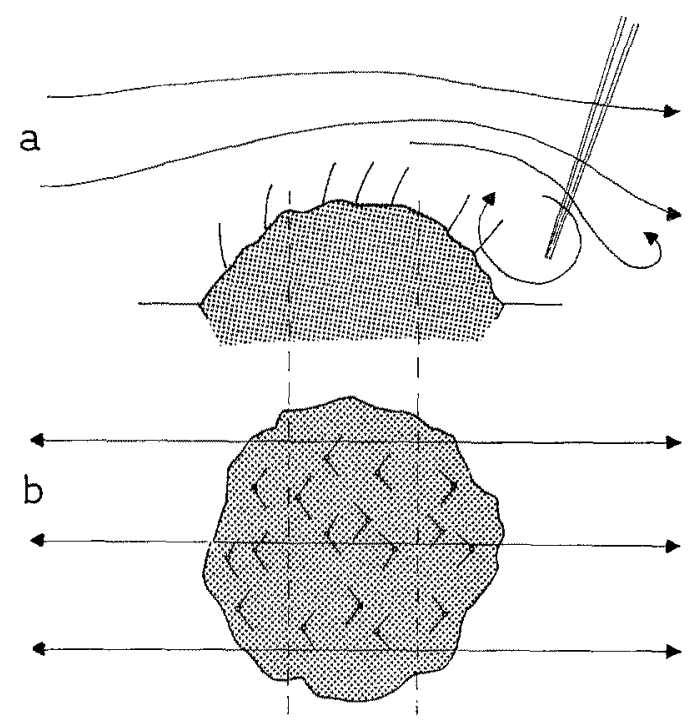

Fig. 6: Orientation of Aglaopbenia pluma fans. a Orientation relative to water movement patterns revealed by whirl studies via injection of air bubbles with a capillary tube. $b$ Orientation as function of substrate region

\section{SUMMARY}

1. Experiments in the natural habitat and under laboratory conditions have been conducted to analyse the factors responsible for the orientation of the fans of the colonial hydroid Aglaophenia pluma. These experiments indicate that the prevailing direction of water movement significantly affects fan positioning.

2. Field experiments reveal that Aglaophenia pluma growing on Cystoseira sp. orientates the dorsal side of its fans towards the base of this algae. After detaching and turning of substrate pieces $A$. pluma colonies lose their fans and re-orientate the regenerating fans prevailing to water current.

3. Laboratory experiments in running water on Aglaopbenia pluma var. teissieri show, as in the field, dorsal fan orientation perpendicular to the water current; however, rate of up growth is much slower than in the field.

4. Simulation of oscillating water movement, characteristic of the natural habitats of the species investigated, was possible via a special, newly designed pump system. The new system is described.

5. The Aglaopbenia pluma var. teissieri fans were fixed with their rocky substrate 
on a turntable and exposed to the oscillating water movement in a current canal. After the fans have been cast off, the oscillating water movement induces a much higher rate of growth than the running water only. The orientation of the fans was strictly perpendicular to the current.

6. On the margins of the substrate exposed to the current, the fans were orientated with their dorsal surface toward the margin; in the centre of the rock fragments the fans are also strictly orientated perpendicular to the current with their dorsal sides showing in either direction.

7. A close study of the flow of current at the edges of the substrate showed that the whirls may diminish or even reverse the current coming from the substrate side. The orientation of the fans with their dorsal side outwards shows that they orientate themselves to the strongest current.

8. The orientation of a developing fan is basically determined by the first polyp. However, by slow, step by step turning of the upgrowing fan, a helically twisted fan could be obtained, indicating that secondary directioning is possible during growth. Twisted fans can also be found occasionally in the field; presumably they grew up under alternating current directions. Aglaophenia pluma var. teissieri exposed to permanent rotation give rise to regenerating fans which are orientated in the same way as the previous set of fans (preceding cast off).

Acknowledgements. I wish to express my thanks to Professor R. RIEDL for suggesting the problem, Prof. O. KINNE for reading and correcting the manuscript. I am grateful to my colleagues J. OT'T, G. \& R. RIEGER and A. Goldschmid for comments and discussions and for their assistance in preparing the drawings. The "1. Zoologisches Institut" University of Vienna, provided me with laboratory facilities and the "Fonds zur Förderung wissenschaftlicher Forschung" Vienna, financed the equipment (Projekt 504, 655).

\section{LITERATURE CITED}

Hückstedt, G., 1963. Aquarienchemie. Franckh, Stuttgart, 88 pp.

- 1963. Aquarientechnik. Franckh, Stuttgart, 91 pp.

Paffenhö̈ER, G.-A., 1968. Nahrungsaufnahme, Stoffumsatz und Energiehaushalt des marinen Hydroidpolypen Clava multicornis. Helgoländer wiss. Meeresunters. 18, 1-44.

RIEDL, R., 1964. 100 Jahre Litoralgliederung seit Josef Lorenz, neue und vergessene Gesichtspunkte. Int. Revue ges. Hydrobiol. 49, 281-305.

- 1966. Biologie der Meereshöhlen. Topographie, Faunistik und OKologie eines unterseeischen Lebensraumes. Eine Monographie. Parey, Hamburg, 636 pp.

Théodor, J. \& Denizot, M., 1965. Contribution a l'étude des Gorgones. I. A propos de l'orientation d'organismes marins fixés végétaux et animaux en fonction du courant. Vie Miliew 16 B, 237-241.

Wainwright, S. A. \& Dillon, J. R., 1968. On the orientation of sea fans (Genus Gorgonia). Biol. Bull. mar. biol. Lab., Woods Hole 136, 130-139.

Author's address: A. SVOBODA

1. Zoologisches Institut

Universität Wien

A-1010 Wien

Dr.-Karl-Lueger-Ring 1

Austria 